\title{
Use of Electronic Payment Instruments and Effect on Cash Management: A Micro Analysis
}

\author{
K.P. Radhika ${ }^{1 *}$ and P. Ambiga Devi \\ ${ }^{1}$ Department of Humanities, PSG College of Technology, Coimbatore, Tamil Nadu, India \\ ${ }^{2}$ Avinashiligam Institute for Home Science and Higher Education for Women University, Coimbatore, Tamil Nadu, India \\ "Corresponding author: kpradhika05@gmail.com
}

\begin{abstract}
The emergence of innovative electronic payment modes in the financial sector has changed the payment dynamics of transactions across countries. The two important modes of card payments offered by the commercial banks are the debit and credit cards in India. This study is an attempt to examine at the micro level the Baumol Tobin model of demand for money in light of the adoption of electronic payment instruments via debit and credit cards among the select households of Coimbatore City for 2017. The estimated results revealed that from across the range of transactions, more than 50 per cent of the respondents chose the mode of cash payment for values lesser than ₹ 10,000. This indicated that cash was preferred more in the case of low-value transactions. Garrett's Ranking technique was used to find the impact of usage of debit and credit cards on the financial parameters of the respondents. The results showed that among the respondents usage of debit and credit cards had the highest impact on the "level of indebtedness", which indicated that the usage of cards for retail purchases substituted cash significantly.

JEL: E42 Monetary Systems; Standards; Regimes; Government and the Monetary System; Payment Systems
\end{abstract}

Keywords: Debit cards, credit cards, demand for money, electronic payments, financial innovations, the Indian banking sector

The technological revolution and innovations in the financial system of India in the last three decades have paved the way for different forms of electronic payment instruments as a substitute for paper currency. This change has created an impact and changed the dynamics of the banking sector, the transaction demand for cash among households and the monetary policy on the higher end. Humphrey et al. (2003) noted that "if a country moves from a wholly paper-based payment system to close to an "all-electronic system", it may save $1 \%$ or more of its GDP annually once the transaction costs are absorbed".

Gandhi (2017) in his speech observed, "The Vision-2018 of Payment and Settlement Systems in India reiterates the commitment of the Reserve Bank of India to encourage greater use of electronic payments by all sections of society to achieve a "less-cash" society. The objective is to facilitate the provision of a payment system for the future that combines the much-valued attributes of safety, security and universal reach with technological solutions which enable faster processing, enhanced convenience, and the extraction and use of valuable information that accompanies payments".

\section{Electronic Payment Instruments in India}

The electronic payment instruments like debit cards, credit cards, NEFT, RTGS, ATMs, the point of sale devices, mobile banking, smart cards, internet banking and WAP banking have opened the channels of financial transactions to the ease of users. These instruments are found to be "welfare enhancing" in the economy owing to their lower cost of capital, reduced financial risks and improved financial intermediation.

The share of electronic payments have made an upward trend by the end of the year 2011-12 
constituting 91 per cent in terms of value from 88 per cent in $2009-10$ and 48 per cent in terms of volume from 35 per cent in 2009-10 (Payment Systems Vision in India: Vision 2012-15 Report, RBI).

\section{Debit and Credit Cards - the boon of the households}

Card payments have formed an integral part of e-payments in India because of the ease of transactions that it has supported customers from paying bills to transferring funds and shopping globally. The technological diffusion in the payment methods has paved the way for increased use of cards (both debit and credit) by households specifically for retail payments and transactions. The ease of operations and the lowering of the transaction costs in this sector have enabled economic agents to reduce their outstanding transaction balances as postulated by the BaumolTobin model of transaction demand for money (1952).

Das and Singh (2010) reported that the Global Retail Development Index (GRDI Report) showed that during 2009-10, the retail sales transactions in India was ₹ 90,000 crore through cards (credit and debit) at Point of Sale (POS) accounting for about 5 per cent of retail sales in India. In other words, card transactions reduced cash transactions in the retail sector by about 5 per cent leading to ₹ 140 crore of savings in currency management for the government.

\section{LITERATURE SURVEY}

The increased adoption of debit and credit cards in India has led researchers to analyse the effects of the same on different aspects of the monetary and financial arena.

Rupa Jajoo and Vani Laturkar (2011) explained that debit cards are the main component of the retail payment system and emphasised that card transactions reduced cash transactions in the retail sector by about 5 per cent and that with the costs for printing banknotes being of the order of ₹ 2800 crore annually card usage at POS leads to about ₹ 140 crore of savings in currency management.

Agrawal and Jain (2012) studied the various financial innovations in banking in India and highlighted the benefits and challenges of innovative banking trends and practices. The study concluded that in today's new business environment, banks and financial institutions are expected to have more creativity and innovation more than ever before. The study suggested that with the introduction of modern methods of payments that are technologically sophisticated, institutions should enable inclusive and low cost solutions.

Nyasha Kaseke (2012) conducted a qualitative survey of consumer use of plastic money, Debit/ ATM cards, Credit cards and VISA/Master cards from 200 respondents during 2011 in Newzealand. The study found that individual factors such as education level and gender had a bearing on the use of plastic money and that there were problems encountered by consumers in relation to security, speed and complexity of use.

Gupta and Aggarwal (2014) in their paper "Financial Innovations and Technologies: Indian Economy 2020 " discussed the various financial innovations that have transformed the Indian economy. The study revealed that these developments have had a significant positive effect on the economy like Venture Capital, microfinance and also various financial technologies like National Electronic Fund Transfer (NEFT), Mobile-Banking. Online share trading, E-banking have played a significant role in changing India.

Studies have explained the significance and impact of adoption of electronic payment instruments in an economy by analyzing the determinants, changes in the monetary mechanism and the structural changes in the financial arena. Micro-level studies will enhance the analysis to find the factors that promote the adoption of electronic payment instruments and determine the impact of usage of these instruments among households.

\section{Need for the study}

The objective of this paper is to analyse at the micro level the determinants of usage of payment instruments and the effect of payment instruments on elements of cash management among households of Coimbatore, Tamil Nadu.

\section{The study was carried out with the following objectives:}

- To describe the socio-economic and banking profile of the respondents. 
- To identify the pattern of usage of cards (debit and credit card) among the respondents.

- To analyse the effect of cards (debit and credit card) on elements of cash management among the respondents.

\section{METHODOLOGY}

The present study was conducted in the Coimbatore City Municipal Corporation of Coimbatore District in Tamil Nadu. The high urban population combined with vibrant industry atmosphere gives rise to increased currency transactions among the households, and hence the present study selected its respondents from Coimbatore city to estimate the adoption of debit and credit cards and their impact on elements of cash management. A scheduled questionnaire was administered to 400 respondents from the five zones of Coimbatore City Corporation, who were working in private organisations, professionals, government employees or businessmen during the study period 2017. The primary data obtained, through the structured questionnaire, were analysed with the help of percentages, tables, charts, Likert's Scaling and Garrett's Ranking Technique.

\section{Findings of the Study}

(a) Socio-Economic Profile of Respondents: The study successfully received data regarding adoption of e-payment instruments from 400 respondents spread in the five zones of Coimbatore City Corporation, with 269 male and 131 female respectively. The distribution of respondents based on their age is given in table 1.

Table 1: Distribution of respondents based on Age

\begin{tabular}{ccccc}
\hline \multirow{2}{*}{ Age } & Sex & Male & Female & Total \\
\hline \multirow{2}{*}{ 20-30 years } & N & 128 & 62 & 190 \\
& $\mathrm{C}$ & 47.58 & 47.33 & 47.5 \\
\multirow{2}{*}{ 31-40 years } & $\mathrm{N}$ & 87 & 36 & 123 \\
& $\mathrm{C}$ & 32.34 & 27.48 & 30.75 \\
41-50 years & $\mathrm{N}$ & 34 & 20 & 54 \\
& $\mathrm{C}$ & 12.64 & 15.27 & 13.5 \\
$51-60$ years & $\mathrm{N}$ & 20 & 13 & 33 \\
& $\mathrm{C}$ & 7.43 & 9.92 & 8.25 \\
& Total & 269 & 131 & 400 \\
\hline
\end{tabular}

Source: Estimates based on primary data survey, 2017; N=number stated and $C=$ percentage to column total.
Majority of men and women were found to be in the age group of $20-30$ years (47.58 per cent and 47.33 per cent respectively) followed by the age group of $31-40$ years.

Table 2 gives the distribution of respondents based on education and occupation, which are considered vital instruments to enhance the use of electronic payments among the respondents.

Table 2: Distribution of respondents based on education and occupation

\begin{tabular}{|c|c|c|c|c|}
\hline Education & Sex & Male & Female & Total \\
\hline \multirow{2}{*}{ Primary } & $\mathrm{N}$ & 63 & 50 & 113 \\
\hline & $\mathrm{C}$ & 23.42 & 38.17 & 28.25 \\
\hline \multirow{2}{*}{ Secondary } & $\mathrm{N}$ & 79 & 25 & 104 \\
\hline & C & 29.37 & 19.08 & 26 \\
\hline \multirow{2}{*}{ Higher Secondary } & $\mathrm{N}$ & 27 & 16 & 43 \\
\hline & $\mathrm{C}$ & 10.04 & 12.21 & 10.75 \\
\hline \multirow{2}{*}{ Degree / Diploma } & $\mathrm{N}$ & 69 & 32 & 101 \\
\hline & C & 25.65 & 24.43 & 25.25 \\
\hline \multirow{3}{*}{ Post Graduation } & $\mathrm{N}$ & 31 & 8 & 39 \\
\hline & $\mathrm{C}$ & 11.52 & 6.11 & 9.75 \\
\hline & Total & 269 & 131 & 400 \\
\hline \multicolumn{5}{|l|}{ Occupation } \\
\hline \multirow{2}{*}{ Private } & $\mathrm{N}$ & 66 & 29 & 95 \\
\hline & C & 24.54 & 22.14 & 23.75 \\
\hline \multirow{2}{*}{ Government } & $\mathrm{N}$ & 59 & 31 & 90 \\
\hline & C & 21.93 & 23.66 & 22.5 \\
\hline \multirow{2}{*}{ Professional } & $\mathrm{N}$ & 65 & 25 & 90 \\
\hline & $\mathrm{C}$ & 24.16 & 19.08 & 22.5 \\
\hline \multirow{3}{*}{ Business } & $\mathrm{N}$ & 79 & 46 & 125 \\
\hline & $\mathrm{C}$ & 29.37 & 35.11 & 31.25 \\
\hline & Total & 269 & 131 & 400 \\
\hline
\end{tabular}

Source: Estimates based on primary data survey, 2017; N = number stated and $C=$ percentage to column total.

Among the respondents, 25.65 per cent of males and 24.43 per cent of females were degree/diploma holders highlighting the fact that the level of education was considered a primary criterion for the understanding and adoption of the electronic payments that substituted cash in daily transactions.

On the occupation front, the respondents who were "self-employed" possessed a high percentage of electronic payments with male (29.37) and female (35.11) respectively, followed by respondents from "private-sector employed" with 24.54 per cent and 
the "government employees" with 23.66 per cent. Empirical supports from literature for the above finding are by Stix (2004), Simiyu; et, al (2012) and Yang and Chin (2013).

Table 3 gives the distribution of respondents based on their income levels. David and Abel (2006), Rinaldi (2011) and Fujiki (2014) have concluded in their studies that income levels, especially the middle-income groups had a positive impact on the higher use of electronic payment instruments for their daily transactions. In this regard, the study also finds that the respondents were mostly in the monthly income category of ₹ $10,000-20,000$ per month.

Table 3: Distribution of the respondents based on income

\begin{tabular}{ccccc}
\hline Income (₹) & Sex & Male & Female & Total \\
\hline Below 10,000 & $\mathrm{N}$ & 71 & 37 & 108 \\
& $\mathrm{C}$ & 26.39 & 28.24 & 27 \\
$10,000-20,000$ & $\mathrm{~N}$ & 100 & 38 & 138 \\
& $\mathrm{C}$ & 37.17 & 29.01 & 34.5 \\
$20,000-40,000$ & $\mathrm{~N}$ & 53 & 30 & 83 \\
& $\mathrm{C}$ & 19.70 & 22.90 & 20.75 \\
More than 40,000 & $\mathrm{N}$ & 45 & 26 & 71 \\
& $\mathrm{C}$ & 16.73 & 19.85 & 17.75 \\
& Total & $\mathbf{2 6 9}$ & $\mathbf{1 3 1}$ & $\mathbf{4 0 0}$ \\
\hline
\end{tabular}

Source: Estimates based on primary data survey, 2017; N = number stated and $C=$ percentage to column total.

(b) Banking Profile of the Respondents: Stix (2004), Mishra (2007) and Yang and Ching (2013) have empirically found that there existed a positive association with account ownership in banks by individuals and the adoption electronic payments instruments among households. The number of respondents based on the "category of bank" and "type of account" maintained are given in table 4 .

Table 4: Respondents based on Category of Bank and Type of Account

\begin{tabular}{ccccc}
\hline & Sex & Male & Female & Total \\
\hline Category of bank & & & & \\
\cline { 1 - 4 } Public & N & 203 & 96 & 299 \\
\multirow{2}{*}{ Private } & $\mathrm{C}$ & 75.46 & 73.28 & 74.75 \\
& $\mathrm{~N}$ & 62 & 34 & 96 \\
& $\mathrm{C}$ & 23.05 & 25.95 & 24
\end{tabular}

\begin{tabular}{ccccc} 
Foreign & $\mathrm{N}$ & 4 & 1 & 5 \\
& $\mathrm{C}$ & 1.49 & 0.76 & 1.25 \\
& Total & $\mathbf{2 6 9}$ & $\mathbf{1 3 1}$ & $\mathbf{4 0 0}$ \\
\hline Type of Account & & & & \\
\hline Savings & $\mathrm{N}$ & 228 & 114 & 342 \\
& $\mathrm{C}$ & 84.76 & 87.02 & 85.5 \\
Current & $\mathrm{N}$ & 41 & 17 & 58 \\
& $\mathrm{C}$ & 15.24 & 12.98 & 14.5 \\
& Total & $\mathbf{2 6 9}$ & $\mathbf{1 3 1}$ & $\mathbf{4 0 0}$ \\
\hline
\end{tabular}

Source: Estimates based on primary data survey, 2017; N=number stated and $C=$ percentage to column total.

Seventy-five per cent of male respondents and 73 per cent of female respondents had an account in the public sector banks in the study area, followed by private sector banks with male 23 per cent and female respondents 25 per cent respectively. 84.76 per cent of male and 87.02 per cent of the female had possessed savings account among the total respondents of the study, indicating higher number of savings-account.

Table 5 gives the summary of the respondents based on their possession of debit and credit cards during the study period. Cards formed the base for electronic transactions among the respondents. The present study also found that 64.31 per cent of male respondents and 67.18 per cent of female respondents used debit cards. Credit cards were used by 53.53 per cent and 58.78 per cent of male and female respondents respectively.

Table 5: Respondents based on Usage of Debit and Credit Cards

\begin{tabular}{|c|c|c|c|c|}
\hline Possess & & Male & Female & Total \\
\hline \multicolumn{5}{|c|}{ Possess Debit Card } \\
\hline \multirow[t]{3}{*}{ Yes } & $\mathrm{N}$ & 173 & 88 & 261 \\
\hline & $\mathrm{C}$ & 64.31 & 67.18 & 65.25 \\
\hline & $\mathrm{N}$ & 96 & 43 & 139 \\
\hline \multirow[t]{2}{*}{ No } & $\mathrm{C}$ & 35.69 & 32.82 & 34.75 \\
\hline & Total & 269 & 131 & 400 \\
\hline \multicolumn{5}{|c|}{ Possess Credit Card } \\
\hline \multirow[t]{2}{*}{ Yes } & $\mathrm{N}$ & 144 & 77 & 221 \\
\hline & C & 53.53 & 58.78 & 55.25 \\
\hline \multirow[t]{3}{*}{ No } & $\mathrm{N}$ & 125 & 54 & 179 \\
\hline & $\mathrm{C}$ & 46.47 & 41.22 & 44.75 \\
\hline & Total & 269 & 131 & 400 \\
\hline
\end{tabular}

Source: Estimates based on primary data survey, 2017; $N=$ number stated and $C=$ percentage to column total. 
(c) The Pattern of usage of Debit and Credit Cards among Respondents: Boeschoten (1998) explained payment behaviour of households and demonstrated the importance of transaction size on the adoption of the payment instrument. The current study analysed the choice of payment instrument among the respondents based on the volume of the transactions of the respondent.

Table 6 summarises the choice of payment instrument based on the value of the transaction amount. The study considered a respondent as an electronic money user if they made payment by electronic money for at least one of the options. The estimated results reveal that across the ranges of the transaction whose values were lesser than ₹ 10,000 , more than 50 per cent of the respondents used "cash" for payment, indicating preference of "cash" frequently for low-value transactions.

Table 6: Choice of payment instrument based on the value of transactions (in percentages)

\begin{tabular}{ccccccc}
\hline $\begin{array}{c}\text { Value of } \\
\text { transaction (₹) }\end{array}$ & $\begin{array}{c}\text { Cash } \\
\text { (A) }\end{array}$ & $\begin{array}{c}\text { Debit } \\
\text { card } \\
\text { (B) }\end{array}$ & $\begin{array}{c}\text { Credit } \\
\text { card } \\
\text { (C) }\end{array}$ & $\begin{array}{c}\text { NEFT } \\
\text { (D) }\end{array}$ & $\begin{array}{c}\text { RTGS } \\
\text { (E) }\end{array}$ & F $^{*}$ \\
\hline Less than 1000 & 64.5 & 22.25 & 13.25 & 0 & 0 & 35.5 \\
$1000-5000$ & 76.5 & 10.5 & 13 & 0 & 0 & 23.5 \\
$5000-10000$ & 57.5 & 17.25 & 24.5 & 0.75 & 0 & 42.5 \\
$10000-50000$ & 29 & 36.5 & 31.5 & 3 & 0 & 71 \\
$50000-100000$ & 36.5 & 21.75 & 31.75 & 5 & 5 & 63.5 \\
Above 100000 & 43.5 & 23.5 & 25.5 & 5.25 & 2.25 & 56.5 \\
\hline
\end{tabular}

Source: Estimates based on primary data survey, 2017; $F^{*}=$ per cent of instruments other than cash for payment $(B+C+D+E)$.

In the study, it was found that debit cards and credit cards were preferred mode of payment for transactions in the range of ₹ 10,000 to $₹ 50,000$ and $₹ 50,000$ to $₹ 1,00,000$ with 36.5 per cent and 31.75 per cent respectively. The combined adoption of financial innovations was highest when the transaction values were in the range of $₹ 10000$ to ₹ 50000 with 71 per cent. The use of electronic money may further reduce the transaction cost by shortening the transaction time, which is in line with the Baumol-Tobin model of the transaction demand for money.

(d) The Frequency of Usage of Debit and Credit Cards among Respondents: The extent of usage of debit and credit cards for various transaction purposes indicates the substitution capacity of these instruments for cash. In this regard, the frequency of usage of debit cards for purposes of "purchase of goods and services", "withdrawal of cash", "deposit of cash", "travel and tickets" and "memberships and subscriptions" were analysed using the percentage distribution of the respondents and are given in table 7 .

Table 7: The Frequency of usage of debit cards (in percentages)

\begin{tabular}{|c|c|c|c|c|c|}
\hline 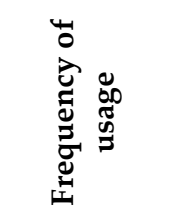 & 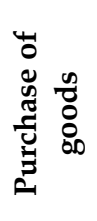 & 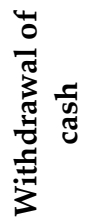 & 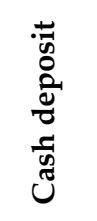 & 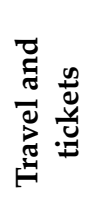 & 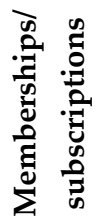 \\
\hline Daily & 45.59 & 6.51 & 0.77 & 4.21 & 0.00 \\
\hline 1-2 days & 29.12 & 40.61 & 15.33 & 3.45 & 4.98 \\
\hline 2-5 days & 16.86 & 30.65 & 34.10 & 28.35 & 16.48 \\
\hline $\begin{array}{l}\text { Once In } 15 \\
\text { Days }\end{array}$ & 3.83 & 13.79 & 15.71 & 25.67 & 18.39 \\
\hline $\begin{array}{l}\text { Once In A } \\
\text { Month }\end{array}$ & 3.45 & 5.36 & 16.09 & 31.80 & 34.48 \\
\hline Never & 1.15 & 3.07 & 18.01 & 6.51 & 25.67 \\
\hline
\end{tabular}

Source: Estimates based on primary data survey, 2017.

Table 8: The Frequency of usage of credit cards (in percentages)

\begin{tabular}{|c|c|c|c|c|c|}
\hline 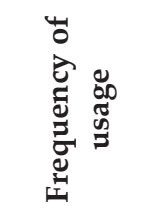 & 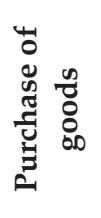 & 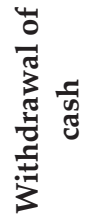 & 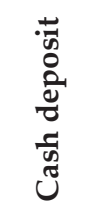 & 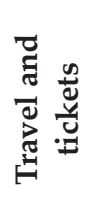 & 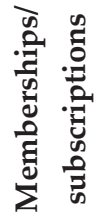 \\
\hline Daily & 9.17 & 0.00 & 0.00 & 0.00 & 0.00 \\
\hline 1-2 days & 10.09 & 0.00 & 0.46 & 3.21 & 1.38 \\
\hline 2-5 days & 12.84 & 4.13 & 0.46 & 11.47 & 6.88 \\
\hline $\begin{array}{c}\text { Once In } 15 \\
\text { Days }\end{array}$ & 23.39 & 17.43 & 11.47 & 25.69 & 13.76 \\
\hline $\begin{array}{l}\text { Once In A } \\
\text { Month }\end{array}$ & 31.19 & 42.66 & 18.53 & 36.24 & 42.20 \\
\hline Never & 13.30 & 35.78 & 69.08 & 23.39 & 35.78 \\
\hline
\end{tabular}

Source: Estimates based on the primary data survey, 2017.

With regard to "Purchase of goods", 45 per cent of the respondents used debit cards on a "daily basis". This revealed that the respondents used debit cards on a higher frequency for the purchase of goods and services. 
The frequency of credit card usage was dependent on the revolving credit facility provided by the bank and the rate of interest charged. Table 8 gives the percentage distribution of frequency of usage of credit cards for various transactions. The respondents used credit cards only once in a month for the different types of transactions, with the highest percentage recorded for "purchase of goods" (31.19 per cent) followed by "cash deposit" (49 per cent), "travel and tickets" (36 per cent) and "memberships and subscription" (42 per cent).

(e) Effect of Debit and Credit Card Usage on Element of Cash Management among Respondents: The analysis of the impact of the usage of debit and credit cards is essential to understand if, in the long run, the increased usage of debit and credit cards will lead to the disappearance of cash. Boeschoten (1992), Duca and Whitesell (1995), Blanchflower et al. (1998), Stix (2004) and Attanasio et al. (2002) have assessed the impact of usage of debit cards and credit cards among households on the various measures of cash demand. In this regard, the present study analysed the impact of "debit and credit cards" on the essential parameters of "cash management" among the respondents.

Following Simiyu et al. (2012), the study identified seven parameters for verifying the influence of usage of debit and credit cards. The parameters include "bank balance", "cash in hand", cash deposits", "cash withdrawal", "amount of savings", "amount of consumption" and "level of indebtedness".

The Likert's five-point scale scoring method was used to score the impacts of usage of the instruments on the elements of cash management. The scores of the respondents were then analysed using Garrett's ranking methodology to find the highest impact on the parameters by ordering them based on the weighted ranks obtained from Garrett's weighted sum and weighted average score.

Based upon the scores assigned by the respondents for the various parameters, the percentage score of the ranked parameters are calculated using Garrett's percentage score formula as:

$$
\text { Percentage position }=100\left(R_{i j}-0.5\right) / N_{j}
$$

Where $R_{i j}=$ Rank given for the $i^{\text {th }}$ variable by $j^{\text {th }}$ respondents

$N_{j}=$ Number of variables ranked by jth respondents.
The percentage obtained for the ranks are then converted into their respective scores using Garrett's table, called the scale value. The weighted sums are obtained by multiplying the number of respondents by the respective scale values and by adding the scores of each rank for every factor. The mean score is then calculated to know the order of impact of usage of debit and credit cards on the parameters. The factor with the highest mean values is said to have greater impact due to the usage of debit and credit cards. The distribution of Garrett's scores is given in table 9 .

Table 9: Distribution of Garrett's scores and ranks

\begin{tabular}{|c|c|c|c|c|c|c|}
\hline $\begin{array}{l}\text { Elements of Cash } \\
\text { Management }\end{array}$ & VMI & MI & NC & MD & VMD & Total \\
\hline Bank balance & 161 & 61 & 155 & 19 & 4 & 400 \\
\hline Cash in hand & 122 & 47 & 186 & 35 & 10 & 400 \\
\hline Cash deposits & 152 & 37 & 172 & 31 & 8 & 400 \\
\hline Cash withdrawals & 156 & 58 & 131 & 41 & 14 & 400 \\
\hline Amount of savings & 132 & 69 & 149 & 35 & 15 & 400 \\
\hline $\begin{array}{l}\text { Amount of } \\
\text { consumption }\end{array}$ & 149 & 49 & 162 & 28 & 12 & 400 \\
\hline Level of indebtedness & 119 & 56 & 172 & 34 & 19 & 400 \\
\hline
\end{tabular}

Source: Estimates based on the primary survey, 2017; VMI = very much increased, $M I=$ moderately increased, $N C=$ No change; $M D$ $=$ Moderately decreased, $V M D=$ very much decreased .

The values in table 9 were used to calculate the percentage score for each ranking factor and thereby to derive at the Garrett's score value using the Garrett's table, which are presented in table 10.

Table 10: Estimated Percentage score and the Garrett score value

\begin{tabular}{cccc}
\hline Rank & $\begin{array}{c}\text { Percentage } \\
\text { calculation }\end{array}$ & $\begin{array}{c}\text { Percentage } \\
\text { score }\end{array}$ & $\begin{array}{c}\text { Garrett's } \\
\text { Score* }^{*}\end{array}$ \\
\hline VMI & $100(5-0.5) / 5$ & 90 & 25 \\
MI & $100(4-0.5) / 5$ & 70 & 40 \\
NC & $100(3-0.5) / 5$ & 50 & 50 \\
MD & $100(2-0.5) / 5$ & 30 & 60 \\
VMD & $100(1-0.5) / 5$ & 10 & 75 \\
\hline
\end{tabular}

Source: Estimates based on the primary survey, 2017. * Garrett's value from Garrett's table; VMI = very much increased, $M I=$ moderately increased, $N C=$ No change; $M D=$ Moderately decreased, $V M D=$ very much decreased .

Using the calculated Garrett's value, the ranking of the parameters is done based on the total sum and the mean obtained for each element of cash 
management. Table 11 gives the order of impact of usage of debit and credit cards among respondents on their elements of cash management based on the ranking obtained. It is evident from the table that debit and credit cards had the highest impact on the "level of indebtedness", indicating that cards have replaced cash predominantly for retail purchases among the respondents in the study.

Table 11: Calculated weighted sum, mean and the rank based on Garrett's Ranking

\begin{tabular}{cccc}
\hline $\begin{array}{c}\text { Elements of cash } \\
\text { management }\end{array}$ & Total score & $\begin{array}{c}\text { Mean } \\
\text { score }\end{array}$ & Rank \\
\hline Bank balance & 15655 & 39.14 & VII \\
Cash in hand & 17080 & 42.70 & II \\
Cash deposits & 16340 & 40.85 & V \\
Cash withdrawals & 16280 & 40.70 & VI \\
Amount of savings & 16735 & 41.84 & III \\
Amount of & & & \\
consumption & 16365 & 40.91 & IV \\
Level of indebtedness & 17280 & 43.20 & I \\
\hline
\end{tabular}

Source: Estimates based on primary survey, 2017.

The second impact was on "cash in hand", bringing out the fact that after inducing credit purchases among respondents with use of credit cards, the increased use of debit cards have reduced the holding of cash in hand by the respondents. Hence, it can be said that debit cards and credit cards have replaced cash thereby causing a decline in the "transaction motive for holding cash" among the respondents.

\section{CONCLUSION}

This study attempted to analyse the Baumol Tobin model of demand for money in light of the adoption of electronic payment instruments via debit and credit cards among the select households of Coimbatore City for 2017. The estimated results revealed that from across the range of transactions, more than 50 per cent of the respondents preferred "cash-payment" for values lesser than ₹ 10,000, indicating its preference for "low-value transactions". Garrett's Ranking technique to analyse the order of impact of usage of debit and credit cards among respondents showed that usage of "debit and credit cards" impacted the "level of indebtedness", indicating that cards dominated the retail purchases among the households of the study.

\section{REFERENCES}

Attanasio, Orazio, Guiso, Luigi and Jappelli, Tullio, 2002. The Demand for Money, Financial Innovation, and the Welfare Cost of Inflation: An Analysis with Household Data, Journal of Political Economy, 110(2): 317-351.

Boeschoten, W.C. 1998. “Cash Management, Payment Patterns and the Demand for Money," De Economist, 146(1): 117142.

Das Ashish and Agarwal Rakhi 2010. Technical Report 2010 http://dspace.library.iitb.ac.in/jspui/handle/10054/1732.

David Bounie and Abel Francois 2006. "Cash, Check or Bank Card? The effects of Transactions Characteristics on the use of Payment Instruments", Working Papers in Economics and Social Sciences, Working Paper ESS-06-05, Available at SSRN: https://ssrn.com/abstract=891791 or http://dx.doi. org/10.2139/ssrn.891791.

Gandhi. R. 2017. Speech by the Deputy Governor of the Reserve Bank of India, at the launch of the Bharat QR Code, Mumbai, 20 February 2017. https://www.bis.org/review/ r170223b.htm

https://www.rbi.org.in/Scripts/PublicationVisionDocuments. aspx?Id=678

Humphrey David, Magnus Willeson, Ted Lindblom and Goran Bergendahl 2003. "What does it cost to make a payment?", Review of Network Economics, 2(2).

Laura Rinaldi 2001. "Payment Cards and Money Demand in Belgium", Center for Economic Studies Discussions Paper Series (DPS) 01.16, http://www.econ.kuleuven.be/ ces/ discussionpapers/default.htm.

Nyasha Kaseke 2012. “Cash or Plastic Money - An Investigation into the Payment mode during Post-multicurrency period in Zimbabwe", Int. J. Adv. Res. Mgt. and Soc. Sc., 1(6): $102-119$.

Rupa Jajoo and Vani Laturkar 2011. “Debit Card Usage in India - A Perspective", Global Economic Research, 1(1): $54-61$.

Simiyu, Justo Simiyu, Momanyi, Gedion, Naibei, Kiprotich Isaac and Odondo, Alphonce Juma 2012. “Credit and Debit Card Usage and Cash Flow Management Control by Customers: Evidences from Commercial Banks Customers in Kisumu City, Kenya", African Research Review, 6(4): 157-172.

Stix, H. Empirica 2004. "How Do Debit Cards Affect Cash Demand? Survey Data Evidence", 31: 93.

Sunita Agrawal and Ankit Jain 2012. “Technological Advancement in Banking Sector in India: Challenges Ahead", Abhinav J. Res. Com. Mgt., 2(1): 89-96.

Sweety Gupta and Aanchal Aggarwal 2014. "Financial Innovations and Technologies: Indian Economy 2020", IOSR Journal of Business and Management (IOSR-JBM), 16(2): 62-67. 
